\title{
The foliar trichomes of Hypoestes aristata (Vahl) Sol. ex Roem. \& Schult var aristata (Acanthaceae) a widespread medicinal plant species in tropical sub-Saharan Africa: with comments on its possible phylogenetic significance
}

\author{
A. Bhatt*, Y. Naidoo and A. Nicholas \\ School of Biological and Conservation Sciences, University of KwaZulu-Natal, Westville Campus, Private Bag X54001, Durban, KZN, 4000, South Africa
}

\begin{abstract}
The micromorphology of foliar trichomes of Hypoestes aristata var. aristata was studied using stereo, light and scanning microscopy (SEM). This genus belongs to the advanced angiosperm family Acanthaceae, for which few micromorphological leaf studies exist. Results revealed both glandular and non-glandular trichomes, the latter being more abundant on leaf veins, particularly on the abaxial surface of very young leaves. With leaf maturity, the density of non-glandular trichomes decreased. Glandular trichomes were rare and of two types: long-stalked capitate and globose-like peltate trichomes. Capitate trichomes were observed only on the abaxial leaf surface, while peltate trichomes were distributed on both adaxial and abaxial leaf surfaces.
\end{abstract}

Key terms: Acanthaceae, Glandular trichomes, Hypoestes aristata var. aristata, medicinal plant, Scanning electron microscope.

\section{INTRODUCTION}

The Family Acanthaceae is a large and diverse family of dicotyledonous plants comprising about 202 genera and 3520 species (Judd et al., 2008); although estimates vary from 2600 (Long 1970) to 4300 species (Mabberly 1990). The family is an ecologically important constituent of many tropical floras. It is the $14^{\text {th }}$ largest family in southern Africa and $15^{\text {th }}$ largest worldwide (Cowling and Hilton-Taylor 1994). The family is noted for producing the most extraordinary range of different and quite elaborate pollen types (Scotland and Vollesen 2000). Several different infrafamilial classifications have been proposed for the Acanthaceae, but no taxonomic consensus has yet been reached (Scotland 1995). On the basis of morphology it has been suggested that the family is not 'natural' (Bremerkamp 1955; 1965). Molecular data has helped botanists move towards a more clearly circumscribed family, by supporting the inclusion of the mangrove genus Avicennia (Schwarzbach and McDade 2002), Thunbergia and others (often receiving their own family status), while excluding the genus Thomandersia (Wortley et al., 2007). This has, however, led to a situation where the family cannot be definitively and distinctively constrained by morphological synapomorphies (Judd et al., 2008). Recent work on the evolution and the diversification of the Acanthaceae provides a phylogenetic context for assessing the taxonomic significance of possible characters (including micromorphological structures) within the family (McDade et al., 2008).

Molecular evidence, from several genes (both chloroplast and nuclear), supports a large monophyletic clade that has been recognized at either the family level, Acanthaceae sensu stricto, or the subfamily level, Acanthoideae (McDade 2000). The genus Hypoestes belongs to this large clade (within the tribe Justicieae, subtribe Diclipterinae (McDade 2000b), which is characterized by colourful, bilabiate, tubular, zygomorphic flowers supported by prominent bracts and producing explosive capsular fruits. Many studies have further supported the placement of Hypoestes in a smaller clade that includes the prominent genus Justicia (McDade and Moody 1999). Morphological synapomorphies that unite this smaller Justicia-lineage include the possession of cystoliths, articulated stems and porate pollen (McDade et al., 2000a).

Hypoestes is considered an important acanthaceous genus that consists of 40 species of woody-based, evergreen perennials, sub-shrubs and shrubs from open woodland in South Africa, Madagascar and S.E. Asia (Ellis 1999). Three species of the genus Hypoestes are reported in southern Africa.

Although some species of Hypoestes are economically important as horticultural plants, they are also of ethnobotanical significance, and a number have interesting secondary metabolites. Different types of fusicoccane and dolabellane diterpenes have been isolated from different species of Hypoestes i.e., H. rosea (Adesomoju and Okogun 1984), H. forskalei (Muhammad et al., 1998), H. serpens (Andriamihaja et al., 2001), H. verticillaris (Al-Rehaily et al., 2002). Rasoamiaranjanahary et al. (2003) isolated two new diterpenes from the leaves of Hypoestes serpens that have shown interesting antifungal activity against both plant pathogenic fungi and yeast.

Hypoestes aristata (Vahl) Sol. ex Roem. \& Schult var. aristata is a shrub commonly known as the ribbon bush. H. aristata var. aristata grows to a height of approximately $1.5 \mathrm{~m}$. The leaves are ovate-acuminate and rough to the touch. The flowers have two lips, with the upper lip being a rich dark purple with white honey-guide markings. This species is native to tropical subSaharan Africa. In South Africa, H. aristata var. aristata is distributed along the wetter eastern side of the subcontinent and is found in the Western Cape, Eastern Cape, KwaZuluNatal, Mpumalanga and Limpopo provinces (Pooley 1998;

* Corresponding Author: Arvind Bhatt, School of Biological and Conservation Sciences, University of KwaZulu-Natal, Westville Campus Private Bag X54001, Durban, KZN, 4000, South Africa, Email: arvin_bhatt@rediffmail.com 
Joffe 2001). A taxonomic revision for the genus in southern Africa was undertaken by Balkwill and Getliffe Norris (1985).

The amaZulu of South Africa use the crushed leaves of $H$. aristata var. aristata for the treatment of sore eyes (Hulme, 1954). Whole plant infusions are used to drench calves suffering from a condition referred to as white scours (Hutchings 1996). Plant decoctions are used in the treatment of breast disease. Roots are chewed for influenza, cough, colds and sore throats in East Africa (Kokwaro 1976). The root bark of $H$. aristata var. aristata is reported to be used for the treatment of malaria (Iwu 1993).

A unique chemistry (as is seen in some species of this genus) may be connected with the medicinal properties of $H$. aristata var. aristata, and in turn this could relate to the glandular trichomes of the leaves.

Although not a universally useful taxonomic character, the structure of folia trichomes have nonetheless proved to be taxonomically useful in some families, such as the Solanaceae (Adedeji et al., 2007), and even in some orders, such as the Urticales (Gangadhara and Inamdar, 2005). Although many taxonomic works on the Acanthaceae mention the presence of folio trichomes, few studies explore in detail the micromorphology of these interesting structures. While the unique hygroscopic hairs of the seed of some species is well known and documented (Balkwill and Getliff Norris 1988), to date no detailed survey of general folio trichomes has been undertaken for the whole of the Acanthaceae, Such a survey may eventually contribute to finding possible morphological synapomorphies that might correlate with the clades postulated using molecular evidence; as has been done with the hygroscopic trichomes of the seeds in the Tribe Whitfieldieae (Manktelow 2001). The correlation of phenotypic characters with genomic may help towards a holistic taxonomy for the Acanthaceae and possibly even aid in a small way to solving family circumscriptions in the problematic order Lamiales. It is the lack of detailed studies of the folio micromorphology of member species of this important family, and Hypoestes in particular, that motivated this investigation. In consequence, this paper examines the morphology and distribution of leaf trichomes of $H$. aristata var. aristata at different stages of leaf development. This paper builds on the initial observations of these trichomes by Balkwill and Getliffe Norris (1985).

\section{MATERIAL AND METHODS}

The leaves of Hypoestes aristata var. aristata were collected from cultivated plants on the University of KwaZulu-Natal, Westville campus. Fresh leaves were used for experimental work and a voucher specimen (Nicholas \& Bhatt, 2994) was also deposited in the Ward herbarium (UDW) at the University of KwaZulu-Natal, Durban campus. Leaves of three different developmental stages were selected for the present study: Stage I- very young (2.0- $4.0 \mathrm{~cm}$ long), Stage II- young (4.1-6.0 cm long) and Stage III- fully expanded (above $6.1 \mathrm{~cm}$ long). Five plants of $H$. aristata var. aristata were sampled and from each plant, five leaves of different developmental stage were used for study. Fresh leaves were examined and photographed with a stereomicroscope (Nikon AZ 100).

For light microscopic studies, semi-thin sections of leaf material were embedded in low viscosity Spurr's (1969) resin. Sections of the resin-embedded tissue, ranging in thickness from $0.5-2 \mu \mathrm{m}$, were cut using glass knives and heat fixed onto pre-cleaned glass slides with drops of distilled water. These sections were stained with $0.5 \%$ Toluidine blue- 0 consisting of $0.1 \%$ sodium carbonate at a pH 11.1 (Feder and O'Brein 1968). Sections were stained for approximately $1 \mathrm{~min}$. over heat, washed briefly in distilled water and mounted in immersion oil. Slides were viewed and photographed with a Leitz light microscope.

For scanning electron microscopy, sections of leaves at different developmental stages were prepared by rapid quenching in liquid nitrogen and freeze dried in an Edwards Modulyo freeze dryer at $-60^{\circ} \mathrm{C}$ in a vacuum of $10-2$ Torr for approximately $48 \mathrm{hrs}$. Leaf segments were secured onto brass stubs with carbon conductive tape and sputter coated with gold for 4 mins. Observations were carried out using a Jeol 6100 scanning electron microscope operated at $12 \mathrm{kV}$, with a working distance of $15 \mathrm{~mm}$.

\section{RESULTS}

Stereomicroscopic observations revealed that the leaves of $H$. aristata var. aristata possess sharply pointed non-glandular trichomes (Fig 1C). These were more abundant on leaf veins and leaf margins, particularly on the abaxial surface of very young leaves (Fig $1 \mathrm{~A}$ and B).

The morphology of peltate trichomes was elucidated with light microscopy. Peltate trichomes consist of a short basal cell embedded in the epidermis and a short stalk cell subtending a large spherical secretory head. It appeared that the head of peltate trichomes consist of multi-cellular central head cells (Fig. 2A). Figure 2B shows the presence of cystoliths on the epidermal layer. Light microscopy investigation revealed that the non- glandular trichomes are outgrowths that originate from the aerial epidermis. These trichomes appear sharply pointed (Figure. 2C).

Scanning electron microscopic investigations revealed that the leaf surfaces of $H$. aristata var. aristata possess both non-glandular and glandular trichomes on the adaxial and abaxial leaf surfaces. A higher density of non-glandular trichomes was observed on abaxial leaf surfaces, particularly on the leaf veins and leaf margin (Fig. 3A and B) as supported by stereomicroscopic observations. Non-glandular trichomes are multicellular and uniseriate, and appear to consist of 3-5 cells. The basal cell is slightly thickened and more opaque than the others, and this may be a consequence of deposits of cellulose, or possibly even silica or calcium. Non-glandular hairs are supported by a cellular pedestal made up of a group of epidermal cells arranged in a circle around the base (Fig. 3C). Cuticular wart-like structures were observed only on the surface of non-glandular trichomes (Fig. 3D). Non-glandular trichomes are bent and point towards the leaf-tip. It was observed that with leaf maturity, the density of non-glandular trichomes decreased as compared to very young leaves (Fig. 3B). This is due to the cells of the leaves expanding during growth, which thereby causes the number of hairs to decrease relative to the increase in surface change.

Two types of glandular trichomes, i.e. long-stalked capitate and round-shaped peltate trichomes, were observed on the leaf surface of $H$. aristata var. aristata. The occurrence of both types of glandular trichomes was infrequent. Long 

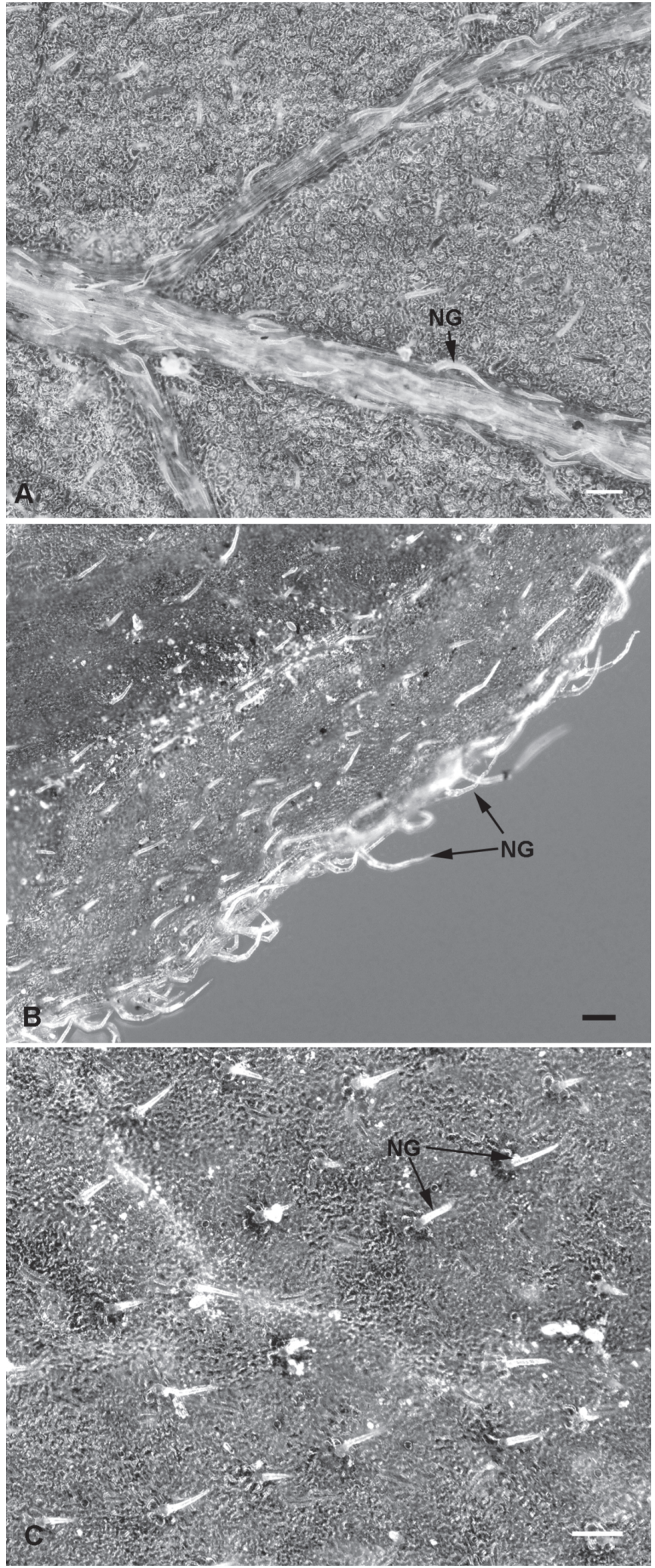

Figure 1: Stereo-micrograph showing distribution of trichomes on Hypoestes aristata var. aristata leaves. A: Leaf vein. B: Leaf margin with numerous non-glandular tichomes and peltate trichome. C: Sharply pointed non-glandular trichomes $(B a r=$ $50 \mu \mathrm{m})$.
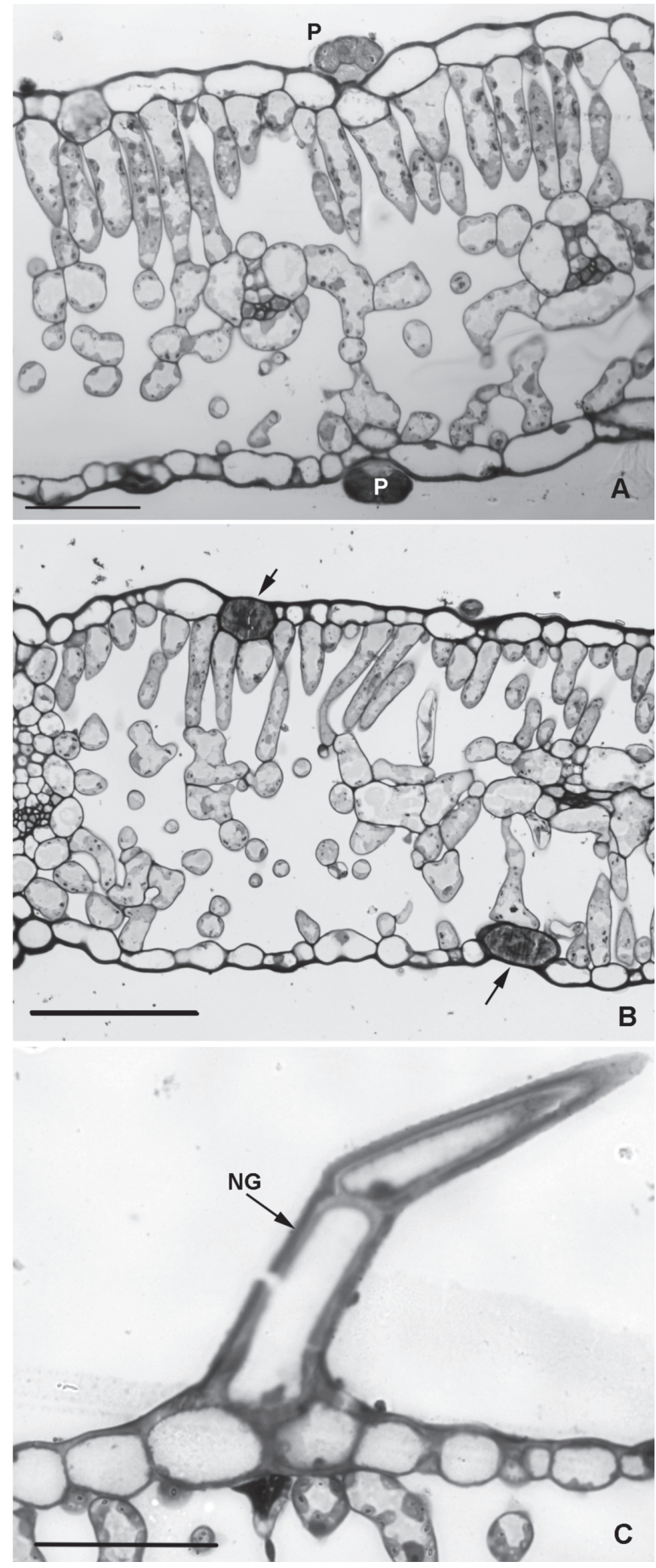

Figure 2: Light micrographs of Hypoestes aristata var. aristata (A) Peltate trichome. (B) Presence of cystoliths on the epidermal layer (arrows) (C) Non-glandular trichomes (NG) $($ Bar $=50 \mu \mathrm{m})$. 



Figure 3: SEM micrographs showing distribution and types of trichomes on Hypoestes aristata var. aristata leaves. A: Distribution of non-glandular trichomes (NG) on leaf vein $(B a r=20 \mu \mathrm{m})$. B: Leaf margin $(B a r=20 \mu \mathrm{m})$. C: Sparse distribution of non-glandular trichomes on mature leaf $(\mathrm{Bar}=20 \mu \mathrm{m})$. D: Fully developed non-glandular trichomes (NG) supported by basal cellular pedestal (CP) on leaf surface $(B a r=10 \mu \mathrm{m})$. E: Distribution of long stalked capitate trichomes (C). Capitate trichomes at different phases of secretion (PS- Pre-Secretory phase; SP- Secretory Phase; Ps- Post secretory phase) (Bar = 10 $\mu \mathrm{m})$. F: Peltate trichomes showing smooth surface $($ Bar $=1 \mu \mathrm{m})$ 
stalked capitate trichomes were seen only on the abaxial leaf surface (Fig. 3E). This type of trichome was observed only on very young leaves. For capitates trichomes, different stages of secretion were observed through the SEM i.e.: Phase IPresecretory, Phase II- Secretory and Phase III- Post secretory (Fig. 3F). Capitate trichomes appear to be supported by a one to two celled stalk. In contrast, the round-shaped peltate trichomes are distributed on both the abaxial and adaxial leaf surfaces. The surface of these peltate trichomes is smooth (Fig. $3 F)$. The different developmental stages of peltate trichomes were observed throughout leaf maturation.

\section{DISCUSSION}

Trichomes are unicellular or multicellular outgrowths that originate from the aerial epidermis and which vary in morphological features, location and mode of secretion (Werker 2000). A long history of published literature indicates that the type and density of trichomes differ among species and may vary in organs of the same plant (Uphof 1962). It has been suggested that non-glandular trichomes serve various functions in plants i.e., to reduce the heat load, reflectance of UV light, provide protection from insects and herbivores, increase tolerance to freezing and maintain water balance in leaves (Werker 2000; Mauricio and Rausher, 1997; Liakoura et al., 1997). Glandular trichomes are associated with the production of chemicals that provide defense against herbivores and pathogens.

The density of non-glandular trichomes in $H$. aristata var. aristata was higher on the leaf veins and leaf margin of young leaves, and decreased with leaf maturity. A higher density of trichomes on the leaf veins and apex is a common trend seen in angiosperms (Oppenheimer 1959). This adaptation is possibly used to limit incoming UV light and thus protect vascular tissue. It is assumed that non-glandular trichomes play an important role in leaf protection, particularly during the early stages of leaf development in $H$. aristata var. aristata. Similar results have been reported in other species (Corsi and Bottega 1999; Tattini et al., 2000; Werker 2000; Valkama et al., 2004). The non-glandular trichome is supported by a basal cellular pedestal. It has been reported that the basal cellular pedestal provides mechanical support and serves as a point for the attachment of trichomes to the epidermis (Payne 1978; Ascensao et al., 1999). The thickened basal cell, also reported by Metcalfe and Chalk (1950), may add extra support to this trichome. The stalk of the non-glandular trichome is densely covered with cuticular warts, which could be indicative of leaf maturity (Werker 2000) and which may be involved in helping the hairs stay free of dust by promoting cleaning during rainfall; the so called 'Lotus effect' (Nosonovsky 2007; Nosonovsky and Bhushan 2007). Although Hypoestes produces simple non-glandular trichomes, other genera of the Acanthaceae, such as Baleria and Ruellia, have been reported to produce compound trichomes that are 2-armed or candelabra-like (Metcalfe and Chalk 1950).

We observed the presence of peltate trichomes on both leaf surfaces. Our findings are consistent with observations in several lamiaceous genera: Salvia officinalis (Corsi and Bottega 1999); Plectranthus ornatus (Ascensão et al., 1999) and Mentha arvensis (Sharma et al., 2003). In H. aristata var. aristata, peltate trichomes were mostly distributed on the inter-vein area of the leaves. A similar pattern of distribution of peltate trichomes was reported in Plectranthus medagascariensis (Ascensão et al., 1998). However, long-stalked capitate trichomes were observed only on the abaxial leaf surface of $H$. aristata var. aristata in the early stages of leaf development. Related literature on Teucrium species (Maleci and Servettaz 1991) showed a similar type of long stalked capitate trichomes to those we observed in $H$. aristata var. aristata. In the Lamiaceae, peltate trichomes are postulated to be the site of production of essential oils, while the long-stalked capitate trichomes may produce essential oils and polysaccharides (Maleci and Giuliani 2006). The function of these glandular hairs in Acanthaceae, however, has not yet been determined but, unlike the Lamiaceae and the closely related family Verbenaceae, this family is not reported to be aromatic. Further research into the histochemical and ultrustructure characterization of glandular trichomes in $\mathrm{H}$. aristata var. aristata would be beneficial in understanding their potential role in the plant.

Molecular studies have resolved the phylogenetic placement of some families in the Lamiales. However, the Acanthaceae and Lamiaceae are part of a large nucleus of phylogenetically unresolved families (Bremer et al., 2002; Olmstead et al., 2001). More data, including micromorphological, are needed to help resolve these complex relationships. Within the Asterid I clade, sometimes called the Lamiids (Soltis et al., 2005), glandular trichomes have been reported for the Gesneriaceae, Plantaginaceae, Scrophulariaceae, Orobanchaceae, Lentibulariaceae and Verbenaceae (Judd et al., 2008). Non-glandular or eglandular hairs, similar to those found in the Acanthaceae and Lamiacaeae, have also been found in the Strychnaceae and Apocynaceae (Naidoo unpublished data). The widespread similarities in structure of both non-glandular and glandular trichomes within the Asterids may or may not have some phylogenetic significance.

We observed that non glandular and peltate trichomes initiate and senesce during all stages of leaf development. These findings are in agreement with Wagner et al. (2004) who reported that some trichomes may senesce during various stages of leaf development. Similar results were reported for other species, where trichome development continues throughout leaf maturity (Oosthuizen and Coetzee 1983; Sharma et al., 2003).

The presence of cystoliths is also interesting. These structures are outgrowths or ingrowths of the epidermal layer that become filled with calcium carbonate. They may be simple or can become quite complex. Cystoliths seem to be associated with Justicia and allies, but are not present in taxa outside of this acanthaceous lineage, they are also not present in the Lamiaceae. They have, however, been reported from the Boraginaceae, Scrophulariaceae and Verbenaceae (Metcalfe and Chalk 1950). Most works on micromorphological structure are descriptive, unfortunately, few attempts have been made establish the phylogenetic significance of these (Cantino 1990). A continued survey of foliar trichomes and other micromorphological structures in the Lamiales (22 families with about 20000 species (Judd et al., 2008)) is needed. However, these should aim to establish their phylogenetic and taxonomic significance, and not just elucidate their structural manifestation. 


\section{ACKNOWLEDGMENTS}

This research was carried out with financial support from the National Research Foundation, South Africa. We thank the staff of the Electron Microscope Unit, UKZN Westville campus for their assistance with the microscopy. Our thanks to A. Rajh for assistance with the photographic plates. The authors would also like to thank Dr Hugh Glen of the KwaZulu-Natal Herbarium, of the Southern African National Biodiversity Institute, for helping track down some of the necessary literature.

\section{REFERENCE}

ADEDEJI O, AJUWON OY, BABAWALE OO (2007) Foliar epidermal studies, organographic distribution and taxonomic importance of trichomes in the family Solanaceae. Internatl J Bot 3(3): 276-282.

ADESOMOJU AA, OKOGUN JI (1984) Roseatoxide and dihypoestoxide: additional new diterpenoids from Hypoestes rosea. J Nat Prod 47:308311.

AL-REHAILY A, AL-YAHYA MA, MIRZA HH, AHMED B (2002) Verticillarone: a new seco-fusicoccane ditrepenoid ketonepoxide from Hypoestes verticillaris. J Asian Nat Prod Res 4: 117-122.

ANDRIAMIHAJA B, MARTIN MT, RASOANAIVO P, FRAPPIER F (2001) A new diterpene from Hypoestes serpens. J Nat Prod 64: 217-218.

ASCENSÃO L, FIGUEIREDO AC, BARROSO JG, PEDRO LG, SCHRIPSEMA J, DEANS SG, SCHEFFER JJC (1998) Plectranthus madagascariensis: morphology of the glandular trichomes, essential oil composition, and its biological activity. Int J Plant Sci_159: 31-38.

ASCENSÃO L, MOTA L, CASTRO, MM (1999) Glandular trichomes on the leaves and flowers of Plectranthus ornatus: morphology, distribution and histochemistry. Ann Bot 84: 437-447.

BALKWILL K, GETIFFE NORRIS F (1985) Taxonomic studies in the Acanthaceae; the genus Hypoestes in southern Africa. S Afr J Bot 51(2):133-144

BALKWILL K, GETIFFE NORRIS F (1988) Classification of the Acanthaceae: a southern African perspective. Missouri Botanical Garden Monographs in Systematic Botany 25: 503-516.

BREMEKAMP CEB (1955) Notes on some acanthaceous genera of controversial position. Acta Botanical Neerlandse 4:644-655.

BREMERKAMP CEB (1965) Delimitation and subdivision of the Acanthaceae. Bulletin of the Botanical Survey of India 7:21-30.

BREMER BK, BREMER K, HEIDARI N, ERIXON P, OLMSTEAD RG, ANDERBERG AA, KÄLLERSJ Q M, BARKHORDARIAN EP (2002) Phylogenetics of asterids based on 3 coding and 3 non-coding chloroplast DNA markers and the utility of non-coding DNA at higher taxonomic levels. Mol Phylogenet Evol 24:271-301.

BREMER K, FRIIS EM, BREMER B (2004) Molecular phylogenetic dating of Asterid flowering plants shows early Cretaceous diversification. Syst Biol 53(3): 496-505.

CANTINO PD (1990) The phylogenetic significance of stomata and trichomes in the Labiatae and Verbenaceae. J Arnold Arboretum 71: 323-370.

CORSI Z, BOTTEGA S (1999) Glandular hairs of Salvia officinalis: New data on morphology, localization and histochemistry in relation to function. Ann Bot 84: 657-664.

COWLING RM, HILTON-TAYLOR C (1994) Patterns of plant diversity and endemism in southern Africa: an overview. Strelitzia 1: 31-52.

Ellis BW (1999) Taylor's Guide to Annuals: how to select and grow more than 400 annuals, biennials, and tender perennials. Houghton Mifflin Co., Boston. 1-448pp

FEDER N, O'BRIEN TP (1968) Plant microtechniques: some principles and new methods. Am J Bot 55: 123-142.

GANGADHARA M, INAMDAR JA (2005) Trichomes and stomata, and their taxonomic significance in the Urticales. Plant Systematics and Evolution 127(2-3): 121-137.

HULME MM (1954) Wild Flowers of Natal. Shuter and Shooter, Pietermaritzburg.

HUTCHINGS A (1996) Acanthaceae, in: Zulu Medicinal Plants. University of Natal Press, Pietermaritzburg. 288-291.

IWU MM (1993) Handbook of African medicinal plants. CRC Press, Florida.
JOFFE P (2001) Creative Gardening with Indigenous Plants. A South African Guide. Briza Publications, Pretoria. 1-372pp.

JUDD WS, CAMPBELL CS, KELLOGG EA, STEVENS PF, DONOGHUE MJ (2008) Lamiids (Euasterids I) in: Plant Systematics: A Phylogenetic Approach. 3rd edition. Sinauer Associates, Sunderland. 459-494.

KOKWARO JO (1976) Medicinal plants of East Africa. East African Literature Bureau.

LIAKOURA $\mathrm{V}$, STEFANOU $\mathrm{M}$, MANETAS $\mathrm{Y}$, CHOLEVAS C, KARABOURNIOTIS G (1997) Trichome density and its UV-B protective potential are affected by shading and leaf position on the canopy. Environ Exp Bot 38:223-229.

LONG RW (1970) The genera of Acanthaceae in the southeastern United State. J Arnold Arbor 51:257-309.

MABBERLEY DJ (1990) The Plant Book. Cambridge University Press, Cambridge. 1-874pp.

MALECI BL, SERVETTAZ O (1991) Morphology and distribution of trichomes in Italian species of Teucrium sect.Chamaedrys (Labiatae) - a taxonomical evaluation. Plant Syst Evol 174 (1-2):83-91.

MALECI BL, GIULIANI C (2006) The glandular trichomes of the Labiatae: A review. Acta Hort 723: 85-90.

MANKTELOW M, MCDADE LA, OXELMAN B, FURNESS CA, BALKWILL M-J (2001) The enigmatic tribe Whitfieldieae (Acanthaceae): Delimitation and phylogenetic relationships based on molecular and morphological data. Systematic Botany 26(1): 104-119.

MAURICIO R, RAUSHER MD (1997) Experimental manipulation of putative selective agents provides evidence for the role of natural enemies in the evolution of plant defense. Int J Org Evolution 51: $1435-1444$

MCDADE LA, MOODY ML (1999) Phylogenetic relationships among Acanthaceae: Evidence from non coding trnL-trnF chloroplast DNA sequences. Am J Bot 86: 70-80.

MCDADE LA (2000) Hybridization and phylogenetics: Special insights from morphology. In Wiens J (ed.) Morphological Data in Phylogenetic Analysis: Recent Progress and Unresolved Problems. Smithsonian Institution Press.146-164 pp.

MCDADE LA, MASTA SE, MOODY ML, WATERS E (2000a) Phylogenetic relationships among Acanthaceae: Evidence from two genomes. Syst Botany 25(1):106-121.

MCDADE LA, DANIEL, TF MASTA SE, RILEY KM (2000b) Phylogenetic relationships within the tribe Justicieae (Acanthaceae): Evidence from molecular sequences, morphology and cytology. Annals of the Missouri Botanical Garden 87(4): 435-458.

MCDADE LA, DANIEL TF, KIEL, C. (2008). Towards a comprehensive understanding of phylogenetic relationships among linages of Acanthaceae s.1. (Lamiales). Am J Bot 95(9): 1136-1152.

METCALFE CR, CHALK L (1950) Acanthaceae in: Anatomy of the Dicotyledons. Vol 2. Claredon Press, Oxford. 1014-1023pp.

MUHAMMAD I, MOSSA JS, RAMADAN AF, EL-FERALY FS, HUFFORD CD (1998) Additional diterpene ketones from Hypoestes forskalei. Phytochemistry 47:1331-1336.

NOSONOVSKY M (2007) Multiscale roughness and stability of superhydrophobic biomimetic interfaces. Langmuir 23:3157-3161.

NOSONOVSKY M, BHUSHAN B (2007) Hierarchical roughness optimization for biomimetic superhydrophobic surface. Ultramicroscopy 107: 969-979.

OLMSTEAD RG, DEPAMPHILIS CW, WOLFE AD, YOUNG ND, ELISONS WJ, REEVES PA (2001) Disintegration of the Scrophulariaceae. Am J Bot 88(2): 348-361.

OOSTHUIZEN L-M, COETZEE J (1983) Morphogenesis of trichomes of Pelargonium scabrum. S Afr J Bot 2: 305-310

OPPENHEIMER HR (1959) Adaptation to Drought: Xerophytism. United Nations Educational Scientific and Cultural Organisation, UNESCO Publication, Paris. 1-54pp.

PAYNE WW (1978) A glossary of plant hair terminology. Brittonia 30(2):239-255

POOLEY E (1998) Hypoestes aristata in: A Field Guide to Wild Flowers KwaZulu-Natal and the Eastern Region. Natal Flora Publications Trust, Durban. 436-437pp.

RASOAMIARANJANAHARY L, MARSTON A, GUILET D, SCHENK K, RANDIMBIVOLOLONA F, HOSTETTMANN K (2003) Antifungal diterpenes from Hypoestes serpens (Acanthaceae). Phytochemistry 62: 333-337.

SCHWARZBACH AE, MCDADE L (2002) Phylogenetic relationships of the mangrove family Avicenniaceae based on chloroplast and ribosomal DNA sequences. Syst Botany 27: 84-98. 
SCOTLAND RW, SWEERE JA, REEVES PA, OLMSTEAD RG (1995) Higher-level Systematics of Acanthaceae determined by chloroplast DNA sequences. Am J Bot 82: 266-275.

SCOTLAND RW, VOLLESEN K (2000) Classification of Acanthaceae. Kew Bulletin 55(3): 513-589.

SHARMA S, SANGWAN NS, SANGWAN RS (2003) Development process of essential oil glandular trichome collapsing in menthol mint. Curr Sci 84: 544-550.

SOLTIS DE, SOLTIS PS, ENDRESS PK, CHASE MW (2005) Asterids in: Phylogeny and Evolution of Angiosperms. Sinauer Associates, Sunderland. 207-236pp.

SPURR AR (1969) A low viscosity epoxy embedding medium for electron microscopy. J Ultrastruct Res 26:31-43.

TATTINI M, GRAVANO E, PINELLI P, MULINACCI N, ROMANI A (2000) Flavonoids accumulate in leaves and glandular trichomes of Phillyrea latifolia exposed to excess solar radiation. New Phytologist 148:69-77.
UPHOF JCT (1962) Plant hairs. Gebriider Borntraeger, Berlin-Nikolassee. VALKAMA E, SALMINEN JP, KORICHEVA J, PIHLAJA K (2004) Changes in leaf trichomes and epicuticular flavonoids during leaf development in three birch taxa. Ann Bot 94: 233-242.

WAGNER GJ, WANG E, SHEPHERD RW (2004) New approaches for studying and exploiting an old protuberance, the plant trichome. Ann Bot 93(1):3-11.

WERKER E (2000) Trichome diversity and development. Adv Bot Res 31:1-35.

WORTLEY AH, RUDALL PJ, HARRIS DJ, SCOTLAND, RW (2005) How much data are needed to resolve a difficult phylogeny? Case study in Lamiales. Syst Biol 54: 697-709.

WORTLEY AH, HARRIS DJ, SCOTLAND RW (2007) On the taxonomy and phylogenetic position of Thomandersia. Syst Bot 32(2):415-444. 
